\title{
Ti-B-C nanocomposite coatings deposited by magnetron sputtering
}

Jonas Lauridsen, N Nedfors, U Jansson, Jens Jensen, Per Eklund and Lars Hultman

\section{Linköping University Post Print}

N.B.: When citing this work, cite the original article.

Original Publication:

Jonas Lauridsen, N Nedfors, U Jansson, Jens Jensen, Per Eklund and Lars Hultman, Ti-B-C nanocomposite coatings deposited by magnetron sputtering, 2012, Applied Surface Science, (258), 24, 9907-9912.

http://dx.doi.org/10.1016/j.apsusc.2012.06.049

Copyright: Elsevier

http://www.elsevier.com/

Postprint available at: Linköping University Electronic Press

http://urn.kb.se/resolve?urn=urn:nbn:se:liu:diva-81812 


\section{Accepted Manuscript}

Title: Ti-B-C nanocomposite coatings deposited by magnetron sputtering

Authors: J. Lauridsen, N. Nedfors, U. Jansson, J. Jensen, P. Eklund, L. Hultman

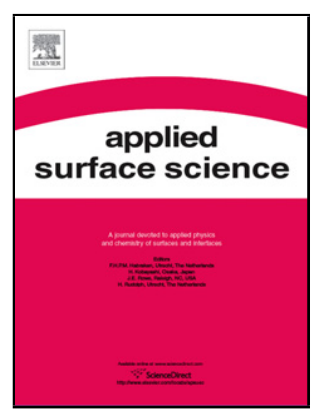

PII:

S0169-4332(12)01099-9

DOI: doi:10.1016/j.apsusc.2012.06.049

Reference: APSUSC 23842

To appear in:

APSUSC

Received date:

31-1-2012

Revised date:

$12-6-2012$

Accepted date:

$14-6-2012$

Please cite this article as: J. Lauridsen, N. Nedfors, U. Jansson, J. Jensen, P. Eklund, L. Hultman, Ti-B-C nanocomposite coatings deposited by magnetron sputtering, Applied Surface Science (2010), doi:10.1016/j.apsusc.2012.06.049

This is a PDF file of an unedited manuscript that has been accepted for publication. As a service to our customers we are providing this early version of the manuscript. The manuscript will undergo copyediting, typesetting, and review of the resulting proof before it is published in its final form. Please note that during the production process errors may be discovered which could affect the content, and all legal disclaimers that apply to the journal pertain. 


\section{Research Highlights}

- Nc-TiC:B/a-BC $\mathrm{x} / \mathrm{a}-\mathrm{C}$ nanocomposite coatings deposited by magnetron sputtering.

- $\mathrm{B}$ is in a solid solution with TiC.

- B induces a rhombohedral distortion of the TiC lattice.

- A contact resistance that is comparable to Ag at loads of $\sim 1 \mathrm{~N}$. 


\section{Ti-B-C nanocomposite}

coatings

\section{magnetron sputtering}

${ }^{a}$ Thin Film Physics Division, Department of Physics, Chemistry, and Biology (IFM),

Abstract

Ti-B-C nanocomposite coatings with a B content of 8-17 at. \%, have been deposited by

11 magnetron sputtering from $\mathrm{B}_{4} \mathrm{C}, \mathrm{Ti}$, and $\mathrm{C}$ targets. X-ray diffraction, photoelectron

12 spectroscopy, and electron microscopy show that the coatings consist of nanocrystalline

13 (nc) TiC:B embedded in a matrix of amorphous (a) C, $\mathrm{BC}_{\mathrm{x}}, \mathrm{TiO}_{\mathrm{x}}$ and $\mathrm{BO}_{\mathrm{x}}$. The fraction of

14 amorphous phase scales with the $\mathrm{Ti}$ concentration, where the matrix predominantly

15 consists of free $\mathrm{C}$ with some $\mathrm{BC}_{\mathrm{x}}$ in coatings with a $\mathrm{C} / \mathrm{Ti}$ ratio $>1$, while the matrix

16 predominantly consists of $\mathrm{BC}_{\mathrm{x}}$ with some free $\mathrm{C}$ in coatings with a $\mathrm{C} / \mathrm{Ti}$ ratio $<1$. Nc-

17 TiC:B/a-BC $\mathrm{x} / \mathrm{a}-\mathrm{C}$ coatings with low amount of free $\mathrm{C}$ exhibit a contact resistance

18 comparable to the contact resistance of an Ag sputtered coating at loads of $\sim 1 \mathrm{~N}$ against

19 an $\mathrm{Au}$ probe, despite the $\mathrm{O}$ content of $\sim 16$ at. \%.

* Corresponding author. E-mail address: jonla@ifm.liu.se (J. Lauridsen).

Linköping University, IFM, SE-581 83 Linköping, Sweden. Tel.: +46 13282976; Fax: +46 13137568.

${ }^{\dagger}$ Present adress: Seco Tools AB, SE-73782 Fagersta, Sweden. 
21 Keywords: Nanocrystalline; Electron microscopy; Contact resistance; $\mathrm{B}_{4} \mathrm{C}$; $\mathrm{TiC}$

\section{1. Introduction}

23 Ti-B-C-based composite coatings have been studied for tribological applications [1,2,3,4],

24 in which B increases the hardness and the wear resistance of TiC. The Ti-B-C ternary

25 phase diagram contains $\mathrm{TiC}, \mathrm{TiB}_{2}$, and $\mathrm{C}$. Thus, the selection of composition in the

26 composite can give a trade-off between the lubricating amorphous $\mathrm{C}$ and probable $\mathrm{BC}_{\mathrm{x}}$

27 phase [5] for good mechanical properties [1,2,3,4] and the hard, but also the conductive

$28 \mathrm{TiC} / \mathrm{TiB}_{2}$ phases $[6,7,8]$, for good electrical properties. Earlier work on Ti-B-C sputtered

29 coatings has suggested that B can be incorporated into $\mathrm{TiC}[6]$ or that nc-TiC is

30 embedded in a quasi-amorphous $\mathrm{TiB}_{2}$ phase $[1,2]$ at low $\mathrm{B}$ content. For high $\mathrm{B}$ contents,

$31 \mathrm{C}$ may be incorporated into $\mathrm{TiB}_{2}[6,9,10]$ or $n c-\mathrm{TiB}_{2}$ may be embedded in a quasi-

32 amorphous TiC phase [1,2]. Similar to the Ti-B-N system [11] an equiaxed

33 nanocrystalline structure can be expected for Ti-B-C coatings due to a segregation-driven

34 renucleation process, and that the coatings contain $\mathrm{TiC}(\mathrm{TiN})$ and $\mathrm{TiB}_{2}$ as the

35 thermodynamically favorable phases. The excess B would segregate to the grain surface

36 and quench crystal growth. The above structure/property-design possibilities in the Ti-B-

37 C system make its coatings interesting for electrical contact applications.

38 Today, noble metals are the most commonly used materials in electrical contacts since

39 they have low resistivity and contact resistance, combined with chemical stability $[12,13]$.

40 The high prices and the low wear resistance in some environments motivate

41 investigations of new electrical contact materials with good electrical properties, but with

42 better mechanical properties than the noble metals. TiC-based nanocomposite materials, 
43 with hard nanocrystalline (nc) TiC embedded in a softer amorphous (a) matrix, e.g., a-C

44 or a-SiC, have been studied for electrical contact applications [14,15,16,17].

45 In the present study low B content Ti-B-C coatings were deposited to study the

46 correlation of the structure and the electrical properties. The as-deposited Ti-B-C coatings

47 are found to have lower contact resistance compared with Ti-Si-C- coatings; however, the

48 resistivity is increased. In particular $\mathrm{C}$-rich coatings are interesting to retain both

49 lubricious and conductive phases. This together with that B improves the mechanical

50 properties of $\mathrm{TiC}$, makes the Ti-B-C system interesting as an electrical contact material.

\section{2. Experimental details}

53 Ti-B-C coatings were deposited by balanced dc magnetron sputtering in an ultra high

54 vacuum deposition system $[18,19]$ (base pressure below $6.5 \times 10^{-7} \mathrm{~Pa}$ ) from two

55 conductive elemental targets (a $50 \mathrm{~mm} \varnothing \mathrm{Ti}$ and a $75 \mathrm{~mm} \varnothing \mathrm{C}$ ) and one conductive

56 compound target (a $75 \mathrm{~mm} \emptyset \mathrm{B}_{4} \mathrm{C}$ ), in an Ar discharge. The targets were positioned 18

$57 \mathrm{~cm}$ from the substrates, two of them at an angle of $35^{\circ}$, and the Ti facing them. Substrates

58 of $\mathrm{Si}$ and $\mathrm{SiO}_{2}$ wafers (both $\left.15 \times 15 \times 0.5 \mathrm{~mm}\right)$, steel $(15 \times 15 \times 1 \mathrm{~mm})$, and Ni-plated $\mathrm{Cu}-$

$596 \mathrm{wt} . \% \mathrm{Sn}(15 \times 15 \times 1 \mathrm{~mm})$ were put on a rotating substrate holder facing the targets.

60 During deposition, a constant dc bias of $-50 \mathrm{~V}$, a Ar pressure of $0.53 \mathrm{~Pa}$ (4 mTorr), and a

61 substrate temperature of $300{ }^{\circ} \mathrm{C}$ were applied. Six coatings were deposited with two

62 different $\mathrm{B}$ concentrations and three different $\mathrm{C} / \mathrm{Ti}$ compositional ratios, respectively,

63 under constant-current conditions, see Table 1. The sample notation is made by

64 normalizing the $\mathrm{Ti}, \mathrm{B}$, and $\mathrm{C}$ contents. 
65 X-ray diffraction (XRD) in gracing incidence (GI) mode with an incidence angle of $2^{\circ}$

66 was performed in a SIEMENS D5000 diffractometer using parallel beam geometry and a

$67 \mathrm{Cu} \mathrm{K \alpha}$ x-ray source operating at $45 \mathrm{kV}$ and $40 \mathrm{~mA}$. Stress measurements using the $\sin ^{2} \psi-$

68 method were performed in a PANalytical Empyrean using $\mathrm{Cu} \mathrm{K} \alpha$ x-ray source operating

69 at $45 \mathrm{kV}$ and $40 \mathrm{~mA}$.

70 Scanning electron microscopy (SEM) was performed in a LEO 1550 microscope. Cross-

71 sectional images were acquired by using accelerating voltage of $10 \mathrm{kV}$ with an Inlens

72 detector. Thickness measurements were done on coatings deposited onto Si substrates.

73 Transmission electron microscopy (TEM) and scanning TEM (STEM) images were

74 obtained with a Tecnai $\mathrm{G}^{2} 20$ U-Twin $200 \mathrm{kV}$ FEGTEM. Analytical TEM was made

75 using energy-dispersive $x$-ray spectroscopy (EDX) in STEM mode. Cross-section

76 samples were mechanically polished to a thickness of $\sim 40 \mu \mathrm{m}$, and ion milled to electron

77 transparency by a Gatan Precision Ion Polishing System (PIPS).

78 X-ray photoelectron spectroscopy (XPS) measurements were carried out using

79 monochromatic $\mathrm{Al} \mathrm{K \alpha}$ radiation in a Physical Electronics Quantum 2000 spectrometer.

80 Energy calibration was carried out with $\mathrm{Au}$ and Ag reference samples. High resolution

81 XPS spectra were acquired after 15 min of sputter etching with $200 \mathrm{eV} \mathrm{Ar}^{+}$ions over an

82 area of $1 \times 1 \mathrm{~mm}^{2}$. The XPS analysis area was set to a diameter of $200 \mu \mathrm{m}$ in all

83 measurements.

84 Time-of-flight energy elastic recoil detection analysis (ToF-E ERDA) at the Uppsala

85 Tandem Laboratory was employed to measure the elemental composition of the six

86 coatings using $40 \mathrm{MeV}^{127} \mathrm{I}^{9+}$ projectile ions at $22.5^{\circ}$ incident angle and a detector placed

87 at a recoil scattering angle of $45^{\circ}$ [20]. The composition results were evaluated with the

88 CONTES code [21]. 
89 Room-temperature four-point-probe measurements were performed using a Jandel

90 Engineering instrument with a WC probe. To obtain the resistivity, the measured sheet

91 resistance was multiplied with the coating thickness obtained in the SEM. Contact

92 resistance was measured with a four-wire in-house setup described in [22]. A current of 1

$93 \mathrm{~mA}$ is applied and the voltage drop is measured. The contact resistance is measured both

94 when the sample is loaded and unloaded by the Au probe. For comparison, the contact

95 resistance is also measured on a dc magnetron sputtered Ag reference sample.

96 The hardness was determined by nanoindentation with an Umis 2000 instrument

97 equipped with a Berkovich indenter. The load was $1 \mathrm{mN}$ and the hardness was an average

98 calculated according to the Oliver-Pharr method [23] from 49 indents.

99 A ball-on-disc test was used to measure the friction coefficient. Ball bearing steel balls, 9

$100 \mathrm{~mm}$ in diameter were used against coatings deposited on steel substrates in ambient air

101 (40\% humidity, $22{ }^{\circ} \mathrm{C}$ ). The friction coefficient was continuously recorded under 5000

102 revolutions, with an applied load of $1 \mathrm{~N}$, a sliding speed of $0.1 \mathrm{~m} / \mathrm{s}$, and a radius of the

103 wear track of $2.5 \mathrm{~mm}$. The friction coefficient value in Table 1 is an average of 5000

104 revolutions.

105 3. Results

106 Table 1 shows the composition of all coatings. Three coatings have a B content of $\sim 8$

107 at.\% and three coatings have a B content of $\sim 16$ at.\%, with a $\mathrm{C} / \mathrm{Ti}$ ratio of $\sim 2.7, \sim 1.8$, and

1080.8 , respectively. All coatings have a $\mathrm{O}$ concentration of $\sim 16$ at. $\%$. The $\mathrm{O}$ contamination

109 comes most probably from the $\mathrm{B}_{4} \mathrm{C}$ target, this is further discussed in the discussion part

110 below. 
111 Figure 1 shows diffraction patterns of the coatings. The $\mathrm{Ti}_{25} \mathrm{~B}_{10} \mathrm{C}_{65}$ has small broad $\mathrm{TiC}$

112 peaks, with a slight peak shift to lower $2 \theta$ values. Coatings $\mathrm{Ti}_{33} \mathrm{~B}_{10} \mathrm{C}_{57}$ and $\mathrm{Ti}_{49} \mathrm{~B}_{10} \mathrm{C}_{40}$

113 show thinner and more intense TiC peaks, with peak shifts similar to the $\operatorname{Ti}_{25} \mathrm{~B}_{10} \mathrm{C}_{65}$

114 coating. The $\mathrm{Ti}_{21} \mathrm{~B}_{19} \mathrm{C}_{60}$ coating with the lowest Ti content appears XRD-amorphous,

115 however, TEM results (below) show that all samples contain nanocrystallites of TiC. The

$116 \mathrm{Ti}_{27} \mathrm{~B}_{20} \mathrm{C}_{52}$ coating exhibits small broad TiC peaks where the TiC 111 peak is shifted to

117 lower $2 \theta$ values, while TiC 200 and 220 are not shifted. The $\mathrm{Ti}_{43} \mathrm{~B}_{19} \mathrm{C}_{38}$ coating has broad

118 TiC peaks; TiC 111 is shifted to lower $2 \theta$ values, while TiC 200 and 220 are shifted to

119 higher $2 \theta$ values. The crystallinity of the coatings increases with increased $\mathrm{Ti}$ content.

120 With increased B content the peaks become broader, the intensity decreases, and the

121 corresponding peak shifts increases. The TiC grain size is estimated by Scherrer's

122 formula to be in the range of $2-9 \mathrm{~nm}$, where coatings with larger $\mathrm{B}$ content have TiC

123 grains with smaller size.

124 To investigate if the peak shifts in XRD are caused by stress or not, stress measurements

125 by the $\sin ^{2} \psi$-method on the $\mathrm{Ti}_{43} \mathrm{~B}_{19} \mathrm{C}_{38}$ coating were made (not shown). The $\mathrm{Ti}_{43} \mathrm{~B}_{19} \mathrm{C}_{38}$

126 coating has a compressive stress below $1 \mathrm{GPa}$, which excludes peak shifts caused by 127 stress.

128 Figure 2 shows the XPS spectra in three regions from the coatings. Figure 2 a shows the

129 Ti2p region, where peaks from both Ti2 $\mathrm{p}_{3 / 2}$ and Ti2 $\mathrm{p}_{1 / 2}$ are observed at $455.0 \mathrm{eV}, 459.1$

$130 \mathrm{eV}, 461.0 \mathrm{eV}$, and $464.6 \mathrm{eV}$, corresponding to Ti-C and Ti-O bonds [24,25]. Note that

131 with increased $\mathrm{Ti}$ content the fraction of Ti-O bonds decreases, and the peak at $455.0 \mathrm{eV}$

132 shifts to lower bonding energies, probably corresponding to Ti-B since B has lower

133 electronegativity than $\mathrm{C}$. Figure $2 \mathrm{~b}$ shows the $\mathrm{C} 1 \mathrm{~s}$ region, where two clear peaks are 
134 observed at 282.0 and $284.5 \mathrm{eV}$, attributed to C-Ti and C-C bonds, respectively [14]. In

135 addition, there is intensity between these two peaks. It can be due to C-B bonds [26],

136 which are expected if $\mathrm{B}$ is dissolved into TiC. However, it can also be due to an

137 interfacial contribution, $\mathrm{C}-\mathrm{Ti}^{*}$, of $\mathrm{C}$ at a matrix/TiC interface described by Lewin et

138 al. [27,28,29]. It is difficult to clearly separate and fit the additional intensity in the C1s

139 peak to these two features, but one example is shown in the top spectrum in Figure $2 b$,

140 where the additional intensity appears to be mainly from $\mathrm{C}-\mathrm{B}$ bonds. The $\mathrm{Ti}_{25} \mathrm{~B}_{10} \mathrm{C}_{65}$ and

$141 \mathrm{Ti}_{21} \mathrm{~B}_{19} \mathrm{C}_{60}$ coatings with a $\mathrm{C} / \mathrm{Ti}$ ratio of $\sim 2.7$, contains mainly free $\mathrm{C}$, with small

142 contributions of $\mathrm{C}-\mathrm{Ti}$ and $\mathrm{C}-\mathrm{B}$. The $\mathrm{Ti}_{33} \mathrm{~B}_{10} \mathrm{C}_{57}$ and $\mathrm{Ti}_{27} \mathrm{~B}_{20} \mathrm{C}_{52}$ coatings with a C/Ti ratio

143 of $\sim 1.7$, contains $\sim 50: 50$ free $\mathrm{C}$ and $\mathrm{C}-\mathrm{Ti}$ bonds with a small contribution from $\mathrm{C}-\mathrm{B}$, and

144 the $\mathrm{Ti}_{49} \mathrm{~B}_{10} \mathrm{C}_{40}$ and $\mathrm{Ti}_{43} \mathrm{~B}_{19} \mathrm{C}_{38}$ coatings with a $\mathrm{C} / \mathrm{Ti}$ ratio of 0.8 , contains mainly $\mathrm{C}$ - $\mathrm{Ti}$,

145 with a low amount of C-B and free C. This means that there is a transition from manly C-

$146 \mathrm{C}$ to $\mathrm{C}-\mathrm{Ti}$ bonds with increased $\mathrm{Ti}$ content in the coatings. Figure $2 \mathrm{c}$ shows the B1s 147 region, where it is observed that the coatings contain $\mathrm{B}-\mathrm{Ti}, \mathrm{B}-\mathrm{C}$, and $\mathrm{B}-\mathrm{O}$ bonds, which 148 originate from peaks at $188.4 \mathrm{eV}, 189.0 \mathrm{eV}$, and $192.0 \mathrm{eV}$, respectively [26,30]. For the

149 coatings with $\sim 8$ at. $\%$ B, a peak shift from B-C to B-Ti bonds is observed with increased

150 Ti content in the coatings, and for the coatings with $\sim 16$ at. $\%, \mathrm{~B}$ bonds mainly to Ti.

152 Figure 3a shows a TEM image with corresponding SAED pattern and a HRTEM image 153 of the $\mathrm{Ti}_{49} \mathrm{~B}_{10} \mathrm{C}_{40}$ coating. Columnar growth with grains of similar size is observed in the 154 overview image. The SAED pattern shows that $\mathrm{TiC}$ is the only crystalline phase, 155 consistent with the XRD results. In the HRTEM image, TiC grains with a size of $\sim 5 \mathrm{~nm}$ 156 (consistent with estimations from XRD with Scherrer's formula) in diameter are observed. 157 Figure $3 \mathrm{~b}$ shows a TEM image with corresponding SAED pattern and a HRTEM image 
158 of the $\mathrm{Ti}_{43} \mathrm{~B}_{19} \mathrm{C}_{38}$ coating. The coating exhibits columnar growth with slightly thinner

159 columns than in the $\mathrm{Ti}_{49} \mathrm{~B}_{10} \mathrm{C}_{40}$ coating. The SAED pattern shows that the only crystalline

160 phase is $\mathrm{TiC}$, as in Coating 3. In the HRTEM image, TiC grains with a size of $\sim 4 \mathrm{~nm}$

161 (consistent with estimations from XRD) are observed. Figure 3c shows the corresponding

162 information from the $\mathrm{Ti}_{21} \mathrm{~B}_{19} \mathrm{C}_{60}$ coating. The overview TEM image shows a featureless

163 structure, without the columnar morphology found in the $\mathrm{Ti}_{49} \mathrm{~B}_{10} \mathrm{C}_{40}$ and $\mathrm{Ti}_{43} \mathrm{~B}_{19} \mathrm{C}_{38}$

164 coatings. The SAED pattern shows blurry rings, indicating nanocrystalline TiC. $\sim 3 \mathrm{~nm}$

165 (consistent with estimations from XRD) large TiC grains are observed in the HRTEM

166 image.

168 Figure 4 shows the contact resistance of all coatings and an $\mathrm{Ag}$ reference. The $\mathrm{Ti}_{25} \mathrm{~B}_{10} \mathrm{C}_{65}$

169 and $\mathrm{Ti}_{21} \mathrm{~B}_{19} \mathrm{C}_{60}$ coatings, with the $\mathrm{C} / \mathrm{Ti}$ ratio of 2 , have the highest contact resistance $(\sim 20$

$170 \mathrm{~m} \Omega$ at $1 \mathrm{~N})$. The other coatings have a contact resistance of $\sim 7 \mathrm{~m} \Omega$ at loads of $\sim 1 \mathrm{~N}$,

171 which is $\sim 5$ times higher than the sputtered Ag reference.

172

173 Table 1 shows the resistivity of all coatings. The resistivity of the coatings (thickness

$174370-690 \mathrm{~nm}$ ) is in the range $380-3990 \mu \Omega \mathrm{cm}$ depending on the $\mathrm{C} / \mathrm{Ti}$ ratio. Decreased

$175 \mathrm{C} / \mathrm{Ti}$ ratio decreases the resistivity.

176

177 The hardness of the coatings is in the range of 10-16 GPa (see Table 1). Increased Ti

178 content increases the hardness of the coating; increased B content has no significant

179 effect on the hardness.

180 
181 Table 1 also shows the friction coefficient of four coatings. The friction coefficient was

182 in the range $0.19-0.33$. Unfortunately, the substrates where coatings $\mathrm{Ti}_{21} \mathrm{~B}_{19} \mathrm{C}_{60}$ and

$183 \mathrm{Ti}_{27} \mathrm{~B}_{20} \mathrm{C}_{52}$ were deposited were too rough for the ball-on-disc measurements to give 184 meaningful results for these two samples.

\section{4. Discussion}

\section{$186 \quad 4.1$ Distribution of B}

187 An important question is: how is B distributed in the coating? The results indicate that B

188 is in solid solution on $\mathrm{C}$ sites in the $\mathrm{TiC}$ lattice as presented as a possibility by ref

189 [6,9], and is part of an amorphous $\mathrm{B}-\mathrm{C}$ matrix, but does not form $\mathrm{TiB}_{2}[1,2]$. The peak

190 shift in XRD with increased B content would correspondingly be due to the incorporation

191 of $\mathrm{B}$ into $\mathrm{TiC}$. If all $\mathrm{Ti}$ in the coating is in the $\mathrm{TiC}$ phase, the amount of $\mathrm{B}$ that is

192 incorporated into the TiC:B can be estimated from XPS data. Thus, the XRD peak shift

193 scales with the amount of B incorporated into TiC:B. For our Ti-B-C coatings, the TiC

194111 is shifted to lower $2 \theta$, i.e., a larger cell parameter, in agreement with the larger atom

195 radii of $\mathrm{B}$ compared with $\mathrm{C}$. However, for the $\mathrm{Ti}_{43} \mathrm{~B}_{19} \mathrm{C}_{38}$ coating, the $\mathrm{TiC} 200$ and 220

196 peaks are shifted to larger $2 \theta$ values. This indicates that $\mathrm{B}$ is preferentially located at the

$197\{111\}$ planes, which also can occur in bulk TiC:B [31]. As the cubic symmetry is 198 interrupted, it yields a rhombohedral TiC:B structure. The rhombohedral distortion of the

199 cubic unit cell in the present coatings is connected with elongation of the body diagonal

200 [111] and a contraction in the other diagonals. This explains why the TiC 111 peak is

201 shifted to lower $2 \theta$ values and TiC 200 and 220 is shifted to higher $2 \theta$ values [32]. The

202 possibility that the peak shift in XRD could be due to that the coatings contain both 203 nanocrystalline $\mathrm{TiC}$ and $\mathrm{TiB}_{2}$, which has been suggested earlier in both Ti-B-C and Ti-C- 
$204 \mathrm{~N}$ coatings, $[1,2,11]$ is excluded on the following grounds: in [1,2] a shift in XRD from $205 \mathrm{nc}-\mathrm{TiC}$ and quasi-amorphous $\mathrm{TiB}_{2}$, to $\mathrm{nc}-\mathrm{TiB}_{2}$ and quasi-amorphous $\mathrm{TiC}$ with increased

206 B content is observed. In [1] it is also shown with SAED that $\mathrm{TiB}_{2}$ is formed at a B/Ti

207 ratio of 1.2 , while $\mathrm{TiC}$ is formed at a $\mathrm{B} / \mathrm{Ti}$ ratio of 0.4 , indicating that the formation of

$208 \mathrm{TiB}_{2}$ requires a high $\mathrm{B}$ concentration. In the coatings studied here, the B content is only

209 8-16 at.\%, favoring the formation of nc-TiC. This is supported by our HRTEM and

210 SAED analyses, which show only crystalline $\mathrm{TiC}$ phase grains and no $\mathrm{TiB}_{2}$. The broad

211 rings in SAED are obviously a consequence of the small grain size. Although the

212 HRTEM images of the $\mathrm{Ti}_{43} \mathrm{~B}_{19} \mathrm{C}_{38}$ coating shows lattice fringes with d-values of $\sim 2.62$

$213 \mathrm{~nm}$, which fits $\mathrm{TiB}_{2}(100)$, no other set of planes could be seen from that phase. Instead,

214 this large d-spacing can be explained as the result of incorporation of B into TiC.

215 Similarly, no $\mathrm{TiB}_{2}$ grains were found in the HRTEM images from the $\mathrm{Ti}_{21} \mathrm{~B}_{19} \mathrm{C}_{60}$ and

$216 \mathrm{Ti}_{49} \mathrm{~B}_{10} \mathrm{C}_{40}$ coatings. Also, the typical XTEM overview image of the coatings (see Figure

217 3a), shows a columnar structure, from the extended growth of $\mathrm{TiC}$ as has been indicative

218 for TiC/C nanocomposite growth [15, 25]. In contrast, B-rich Ti-B-C coatings have a

219 more homogenous if not featureless structure as $\mathrm{TiB}_{2}$ tends to form in the coatings $[1,11]$.

221 Worth mentioning is also that with increased Ti and $\mathrm{B}$ content, $\mathrm{B}$ bonds to $\mathrm{C}$, and the $\mathrm{BC}_{\mathrm{x}}$

222 concentration increases in the amorphous matrix since the concentration of free $\mathrm{C}$

223 decreases. This means that with increased $\mathrm{Ti}$ and $\mathrm{B}$ content the amorphous matrix that

224 first consist mostly of free $\mathrm{C}$ is replaced by $\mathrm{BC}_{\mathrm{x}}$. 


\section{$225 \quad 4.2$ Composition of the amorphous matrix}

226 The higher intensity of the XRD TiC:B peaks from the $\mathrm{Ti}_{33} \mathrm{~B}_{10} \mathrm{C}_{57}$ and $\mathrm{Ti}_{27} \mathrm{~B}_{20} \mathrm{C}_{52}$ 227 coatings compared with the $\mathrm{Ti}_{25} \mathrm{~B}_{10} \mathrm{C}_{65}$ and $\mathrm{Ti}_{21} \mathrm{~B}_{19} \mathrm{C}_{60}$ coatings indicate that increased

228 Ti content lead to higher crystallinity of the coatings. However, the coatings with higher

229 B content have lower crystallinity, indicating that the B impedes TiC growth, which is in

230 agreement with [1,2]. This is also supported from the overview TEM images, where it is

231 observed that the $\operatorname{Ti}_{43} \mathrm{~B}_{19} \mathrm{C}_{38}$ coating with higher $\mathrm{B}$ content than the $\mathrm{Ti}_{49} \mathrm{~B}_{10} \mathrm{C}_{40}$ coating

232 has a smaller column width.

233 The matrix in the $\mathrm{Ti}_{25} \mathrm{~B}_{10} \mathrm{C}_{65}$ and $\mathrm{Ti}_{21} \mathrm{~B}_{19} \mathrm{C}_{60}$ coatings consists mainly of free $\mathrm{C}$. In

234 agreement with previous reports [22], an increased amount of amorphous matrix

235 correlates with a decreased grain size in TiC-based nanocomposites. Therefore, in

$236 \mathrm{Ti}_{21} \mathrm{~B}_{19} \mathrm{C}_{60}$ the growth of crystalline phases is quenched. It is interesting that essentially

237 crystalline coatings can be obtained by adding only a few atomic percent Ti. This was the

238 case for the $\mathrm{Ti}_{25} \mathrm{~B}_{10} \mathrm{C}_{65}$ coating. Higher Ti content also results in decreased amount of free

$239 \mathrm{C}$, and higher concentration of TiC:B, which leads to lower amount of amorphous matrix

240 that can quench the grain growth. The $\mathrm{Ti}_{49} \mathrm{~B}_{10} \mathrm{C}_{40}$ and $\mathrm{Ti}_{43} \mathrm{~B}_{19} \mathrm{C}_{38}$ coatings with the

241 highest $\mathrm{Ti}$ content have the highest peak intensity in XRD, indicating the highest

242 crystallinity of the coatings. These coatings contain no or just a small amount of free C;

243 all C is instead bonded to Ti or B. In the Ti2p region from the XPS spectra, the peak at

$244455 \mathrm{eV}$ is shifted to lower binding energies, meaning that a higher concentration of $\mathrm{Ti}$

245 bonds to B instead of C. The peak shift in Ti2p with increased Ti content is supported by

246 a peak shift in the B1s region, from B-C bonds to more B-Ti bonds. With an increased Ti

247 content more B is incorporated into the TiC:B, and the amorphous matrix that has mostly 248 contained free $\mathrm{C}$ and $\mathrm{BC}_{\mathrm{x}}$ will now mostly consist of $\mathrm{BC}_{\mathrm{x}}$. 
249 The $\mathrm{O}\left(\sim 16\right.$ at. \% O) contamination comes most probably from the $\mathrm{B}_{4} \mathrm{C}$ target since an $\mathrm{O}$

250 content of 8 at.\% through the target was determined with XPS. Similar values of O in

251 other Ti-B-C coatings have been reported in the literature, where the explanation has

252 been additional $\mathrm{O}$ absorption by $\mathrm{Ti}$ in the $\mathrm{TiC}_{\mathrm{TiB}} \mathrm{Tir}_{2}$ target $[10,33]$. However, the $\mathrm{O}$

253 content were higher in coatings with higher B content [10], indicating that it is the B that

254 absorbs $\mathrm{O}$. That is what we think happens in our coatings, i.e., $\mathrm{B}$ in the $\mathrm{B}_{4} \mathrm{C}$ target absorb

$255 \mathrm{O}$. The matrix is affected by the $\mathrm{O}$ content in that way that $\mathrm{O}$ is bonded to both $\mathrm{Ti}$ and $\mathrm{B}$.

256 From XPS data it is seen that the Ti-O contribution decreases with increased Ti content,

257 and that the B-O contribution increases with increased B content, probably since Ti forms

258 carbide instead, and that more $\mathrm{B}$ is available. However, it is unclear how the $\mathrm{O}$ is

259 distributed, if it is only randomly in the matrix, or if it is located around the crystalline 260 grains.

\section{$261 \quad 4.3$ Electrical properties}

262 The change in phase composition of the TiC:B and the amorphous matrix with increased

263 Ti content, also decreases the resistivity as well as the contact resistance of the coatings.

264 The $\mathrm{Ti}_{25} \mathrm{~B}_{10} \mathrm{C}_{65}$ and $\mathrm{Ti}_{21} \mathrm{~B}_{19} \mathrm{C}_{60}$ coatings with high amount of free $\mathrm{C}$ have the highest

265 resistivity and contact resistance. The $\mathrm{Ti}_{43} \mathrm{~B}_{19} \mathrm{C}_{38}$ coating with the highest amount of $\mathrm{Ti}$

266 and B has the lowest resistivity and contact resistance, a contact resistance comparable

267 with $\mathrm{Ti}-\mathrm{A}-\mathrm{C}-\mathrm{Ag}(\mathrm{A}=\mathrm{Si}, \mathrm{Ge}, \mathrm{Sn}$ or $\mathrm{Cu})$ nanocomposite coatings [34] and $\mathrm{Ag}$ against an

$268 \mathrm{Au}$ probe at loads of $\sim 1 \mathrm{~N}$. This is because a higher Ti content leads to higher

269 concentration of the crystalline phase, the phase that is the most conductive in this

270 material system. Increased B content for the corresponding coatings leads to higher 
271 incorporation of $\mathrm{B}$ into the TiC:B, and lower resistivity and contact resistance, indicating

272 that $\mathrm{TiC}: \mathrm{B}$ is more conductive than TiC.

273 Both $\operatorname{TiB}_{2}(270 \mu \Omega \mathrm{cm})$ and $\mathrm{TiC}(80 \mu \Omega \mathrm{cm})$ coatings have lower resistivity than the Ti-

274 B-C coatings [35,36], however, these coatings are too hard and brittle which leads to

275 increased contact resistance [15]. The resistivity for the Ti-B-C coatings are in general

276 also higher $\left(\sim 10^{3} \mu \Omega \mathrm{cm}\right)$ than for Ti-A-C-Ag $(\mathrm{A}=\mathrm{Si}, \mathrm{Ge}, \mathrm{Sn}$ or $\mathrm{Cu})$ coatings $\left(\sim 10^{2} \mu \Omega\right.$

$277 \mathrm{~cm}$ ) [22] or for other comparable nanocomposites [37,38,39,40]. However, the contact

278 resistance is comparable, and the contact resistance is just a factor $\sim 5$ larger than for $\mathrm{Ag}$

279 against $\mathrm{Ag}$, which is remarkable since the coatings contains $\sim 16$ at.\% O. It is unclear how

280 much the $\mathrm{O}$ affects the electrical properties, but the $\mathrm{O}$ contamination is expected to

281 increase both the resistivity and the contact resistance significantly. Nevertheless, these $\mathrm{O}$

282 containing Ti-B-C coatings have qualities as electrical contact material.

\section{$283 \quad 4.4$ Mechanical properties}

284 The hardness of the coatings is lower than for $\mathrm{TiC}$ [25], and also lower than in earlier 285 reports on the hardness of Ti-B-C coatings [41,42], and it did not increase with the

286 incorporation of $\mathrm{B}$, which was reported before $[1,2,3,4]$. This is probably an affect off a

287 larger fraction of soft amorphous matrix in these coatings compared with [41,42]. This

288 also explains the low coefficient of friction against steel, with values comparable to what

289 was published in [41]. The friction coefficients in these Ti-B-C coatings do not seem to

290 vary significantly, which means that the increased amount of free $\mathrm{C}$ did not improve the

291 tribological behavior. How large affect the incorporation of $\mathrm{O}$ into the coatings has on the

292 mechanical properties is unclear. That the coatings have a hardness of $\sim 12 \mathrm{GPa}$ is not a

293 drawback in an electrical contact application, it is harder than the noble metals, and has a 
294 lower coefficient of friction compared with Ag against Ag $(\mu=1.2)$ [22], which make

295 these coatings promising as electrical contact material.

\section{5. Conclusions}

297 Ti-B-C nanocomposite coatings with low B content deposited by magnetron sputtering

298 from $\mathrm{B}_{4} \mathrm{C}, \mathrm{Ti}$, and $\mathrm{C}$ targets consist of nanocrystalline (nc) TiC:B embedded in a matrix

299 of amorphous (a) $\mathrm{C}, \mathrm{BC}_{\mathrm{x}}, \mathrm{TiO}_{\mathrm{x}}$, and $\mathrm{BO}_{\mathrm{x}}$. The most likely position of $\mathrm{B}$ in the coatings is

300 as a solid solution with TiC with a rhombohedral distortion of the cubic structure from

301 ordering on the $\{111\}$ planes. The amount of amorphous matrix in the coatings is

302 controlled by the Ti content. Increased Ti content leads to less free $\mathrm{C}$ and more $\mathrm{BC}_{\mathrm{x}}$ in the

303 matrix, and more $\mathrm{B}$ incorporated into the $\mathrm{TiC}: \mathrm{B}$. In consequence, the contact resistance is

304 lowered for the coatings against an Au probe at loads of $\sim 1 \mathrm{~N}$ to values comparable to $\mathrm{Ag}$,

305 in spite of the high resistivity and a $\mathrm{O}$ content of $\sim 16$ at.\%. Thus, nc-TiC:B/a-BC $/ \mathrm{a}-\mathrm{C}$

306 coatings present an interesting alternative as electrical contact material.

\section{Acknowledgments}

308 The authors whish to acknowledge Fang Mao at the department of Chemistry, Ångström

309 Laboratory, Uppsala University, for the assistance with the ball-on-disk measurements.

310 The work was financially supported by the VINNOVA VINN Excellence Centre in

311 Research and Innovation on Functional Nanoscale Materials, FunMat.

312

313

314

315

316 
321

322

323

324

325

326

327

328

329

330

331

332

333

334

335

336

337

338

339

340

341

342

343

344

345

346

347

348

349

350

351

352

353

354

355

356

357

358

359

360
Table 1. The composition determined with ERDA, resistivity, hardness, and friction coefficient of the coatings.

\begin{tabular}{|c|c|c|c|c|c|c|c|c|}
\hline Coating & $\begin{array}{c}\text { C } \\
\text { [at.\%] }\end{array}$ & $\begin{array}{c}\mathrm{Ti} \\
\text { [at.\%] }\end{array}$ & $\begin{array}{c}\text { B } \\
\text { [at.\%] }\end{array}$ & $\begin{array}{c}0 \\
\text { [at.\%] }\end{array}$ & $\mathrm{C} / \mathrm{Ti}$ & $\begin{array}{c}\text { Resistivity } \\
(\mu \Omega \mathrm{cm})\end{array}$ & $\begin{array}{c}\text { Hardness } \\
\quad(\mathrm{GPa})\end{array}$ & $\mu_{\text {Steel }}$ \\
\hline $1\left(\mathrm{Ti}_{25} \mathrm{~B}_{10} \mathrm{C}_{65}\right)$ & 55 & 21 & 8 & 16 & 2.6 & 2590 & 10 & 0.29 \\
\hline $2\left(\mathrm{Ti}_{33} \mathrm{~B}_{10} \mathrm{C}_{57}\right)$ & 47 & 27 & 8 & 17 & 1.7 & 1840 & 12 & 0.19 \\
\hline $3\left(\mathrm{Ti}_{49} \mathrm{~B}_{10} \mathrm{C}_{40}\right)$ & 35 & 43 & 9 & 13 & 0.8 & 850 & 16 & 0.33 \\
\hline $4\left(\mathrm{Ti}_{21} \mathrm{~B}_{19} \mathrm{C}_{60}\right)$ & 50 & 18 & 16 & 16 & 2.8 & 3990 & 10 & - \\
\hline $5\left(\mathrm{Ti}_{27} \mathrm{~B}_{20} \mathrm{C}_{52}\right)$ & 44 & 23 & 17 & 16 & 1.9 & 1100 & 11 & - \\
\hline $6\left(\mathrm{Ti}_{43} \mathrm{~B}_{19} \mathrm{C}_{38}\right)$ & 32 & 36 & 16 & 16 & 0.9 & 380 & 16 & 0.31 \\
\hline
\end{tabular}


361

362

363

364

365

366

367

368

369

370

371

372

373

374

375

376

377

378

379

380

381

382

383

384

385

386

387

388

389

390

391

392

393

394

395

396

397

398

399

Figure 1. GI-XRD diffractograms of all coatings.

Figure 2. XPS spectra from three regions, a) Ti2p, b) C1s, and c) B1s, of all coatings.

Figure 3. TEM overview micrograph with corresponding SAED pattern and HRTEM image from a)

$\mathrm{Ti}_{49} \mathrm{~B}_{10} \mathrm{C}_{40}$, b) $\mathrm{Ti}_{43} \mathrm{~B}_{19} \mathrm{C}_{38}$, and c) $\mathrm{Ti}_{21} \mathrm{~B}_{19} \mathrm{C}_{60}$ coatings. Some of the nanocrystalline grains are outlined by solid lines.

Figure 4. Contact resistance measurements of all coatings and a sputter deposited Ag reference.

9

(1)


[1] C. Mitterer, P. H. Mayrhofer, M. Beschliesser, P. Losbichler, P. Warbichler, F. Hofer, P. N. Gibson, W. Gissler, H. Hruby, J. Musil, J. Vlček, Surf. Coat. Technol. 120-121 (1999) 405-411.

[2] J.-T. Ok, I.-W. Park, J. J. Moore, M. C. Kang, K. H. Kim, Surf. Coat. Technol. 200 (2005) 1418-1423.

[3] D. Vallauri, I. C. Atias Adrián, A. Chrysanthou, J. Eur. Ceram. Soc. 28 (2008) 1697-1713.

[4] M. Stüber, V. Schier, H. Holleck, Surf. Coat. Technol. $74-75$ (1995) 833-837.

[5] S. Yoon, J. Kim, B. D. Kim, C. Lee, Surf. Coat. Technol. 205 (2010) 1962-1968.

[6] C. Mitterer, M. Rauter, P. Rödhammer, Surf. Coat. Technol., 41 (1990) 351-363.

[7] G. B. Raju, B. Basu, A. K. Suri, Int. J. Refract. Met. Hard Mater. 28 (2010) 174179.

[8] C. M. T. Sanchez, B. Rebollo Plata, M. E. H. Maia da Costa, F. L. Freire Jr. Surf. Coat. Technol. 205 (2011) 3698-3702.

[9] O. Knotek, R. Breidenbach, F. Jungblut, F. Löffler, Surf. Coat. Technol., 43 (1990) $107-115$.

[10] M. D. Abad, J. C. Sánchez-López, M. Brizuela, A. Garcia-Luis, D. V. Shtansky, Thin Solid Films 518 (2010) 5546-5552.

[11] P. H. Mayrhofer, C. Mitterer, J. G. Wen, I. Petrov, J. E. Greene, J. Appl. Phys., 100 (2006) 044301.

[12] M. Antler, Thin Solid Films 84 (1981) 245-256.

[13] P. G. Slade, ed., Electrical Contacts - Principles and Applications, CRC Press, Taylor \& Francis Group, New York, 1999. 
[14] E. Lewin, O. Wilhelmsson, U. Jansson, J. Appl. Phys. 100 (2006) 054303.

[15] P. Eklund, J. Emmerlich, H. Högberg, O. Wilhelmsson, P. Isberg, J. Birch, P. O.

Å. Persson, U. Jansson, L. Hultman, J. Vac. Sci. Technol. B 23 (2005) 2486-2495.

[16] J. Lauridsen, P. Eklund, J. Jensen, H. Ljungcrantz, Å. Öberg, E. Lewin, U. Jansson, A. Flink, H. Högberg, L. Hultman, Acta Materialia 58 (2010) 6592-6599.

[17] U. Jansson, E. Lewin, M. Råsander, O. Eriksson, B. André, U. Wiklund, Surf. Coat. Technol. 206 (2011) 583-590.

[18] J. Emmerlich, H. Högberg, S. Sasvári, P. O. Å. Persson, L. Hultman, J.-P. Palmquist, U. Jansson, J. M. Molina-Aldareguia, Z. Czigány, J. Appl. Phys. 96 (2004) 4817-4826.

[19] J. Frodelius, P. Eklund, M. Beckers, P.O.Å. Persson, H. Högberg, L. Hultman, Thin Solid Films 518 (2010) 1621-1626.

[20] Y. Zhang, H. J. Whitlow, T. Winzell, I. F. Bubb, T. Sajavaara, J. Jokinen, K. Arstila, J. Keinonen, Nucl. Instrum. Methods Phys. Res. B 149 (1999) 477-489.

[21] M. S. Janson, CONTES instruction manual, 2004.

[22] J. Lauridsen, TiC-based nanocomposite coatings as electrical contacts, $\mathrm{PhD}$ Thesis, ISBN: 978-91-7393-030-7, Linköping, Sweden, 2011.

[23] W. C. Oliver, G. M. Pharr, J. Mater. Res. 7 (1992) 1564-1580.

[24] J. Chastain, R. King Jr., Handbook of X-ray Photoelectron Spectroscopy, Physical Electronics, Eden Prarie, MN, 1995.

[25] J. Lauridsen, P. Eklund, T. Joelsson, H. Ljungcrantz, Å. Öberg, E. Lewin, U. Jansson, M. Beckers, H. Högberg, L. Hultman, Surf. Coat. Technol. 205 (2010) 299-305. 
[26] H. A. Castillo, E. Restrepo-Parra, J. M. Vélez, W. de la Cruz, Surf. Coat. Technol. 205 (2011) 3607-3612.

[27] E. Lewin, P. O. Å. Persson, M. Lattemann, M. Stüber, M. Gorgoi, A. Sandell, C. Ziebert, F. Schäfers, W. Braun, J. Halbritter, S. Ulrich, W. Eberhardt, L. Hultman, H. Siegbahn, S. Svensson, U. Jansson, Surf. Coat. Technol. 202 (2008) 3563-3570.

[28] E. Lewin, M. Gorgoi, F. Schäfers, S. Svensson, U. Jansson, Surf. Coat. Technol. 204 (2009) 455-462.

[29] M. Magnuson, E. Lewin, L. Hultman, U. Jansson, Phys. Rev. B 80 (2009) 235108.

[30] R. Gilmore, M. A. Baker, P. N. Gibson, W. Gissler, Surf. Coat. Technol. 105 (1998) 45-50.

[31] G. E. Hollox, Microstructure and mechanical behavior of carbides, seventh technical report, NASA, 1968.

[32] N. A. Dubrovinskaia, L. S. Dubrovinsky, S. K. Saxena, R. Ahuja, B. Johansson, J. Alloys Compd. 289 (1999) 24-27.

[33] S. Shimada, M. Takahashi, J. Tsujino, I. Yamazaki, K. Tsuda, Surf. Coat. Technol. 201 (2007) 7194-7200.

[34] J. Lauridsen, P. Eklund, J. Jensen, A. Furlan, A.Flink, A.M. Andersson, U. Jansson, L. Hultman, Thin Solid Films 520 (2012) 5128-5136.

[35] A. Shutou, T. Matsui, H. Tsuda, H. Mabuchi, K. Morii, Mat. Lett., 45 (2000) 143148.

[36] H. Högberg, J. Birch, M. Odén, J.-O. Malm, L. Hultman, U. Jansson, J. Mater. Res. 16 (2001) 1301-1310.

[37] J. E. Krzanowski and J. L. Endrino, Mater. Lett. 58 (2004) 3437-3440. 
[38] M. D. Abad, J. C. Sánchez-López, N. Cusnir, R. Sanjinés, J. Appl. Phys. 105 (2009) 033510.

[39] M.D. Abad, R. Sanjinés, J.L. Endrino, R. Gago, J. Andersson, J.C. Sánchez-López Plasma Process and Polym. 8 (2011) 579-588.

[40] P. Eklund Surface Engineering 23 (2007) 406-411.

[41] M. D. Abad, D. Cáceres, Y. S. Pogozhev, D. V. Shtansky, J. C. Sánchez-López, Plasma Process. Polym. 6 (2009) S107-S112.

[42] M. Y. Liu, J. Y. Yan, S. Zhang, L. Dong, M. Cao, X. Y. Deng, D. J. Li, IEEE Transactions on Plasma Science 39 (2011) 3115-3119. 


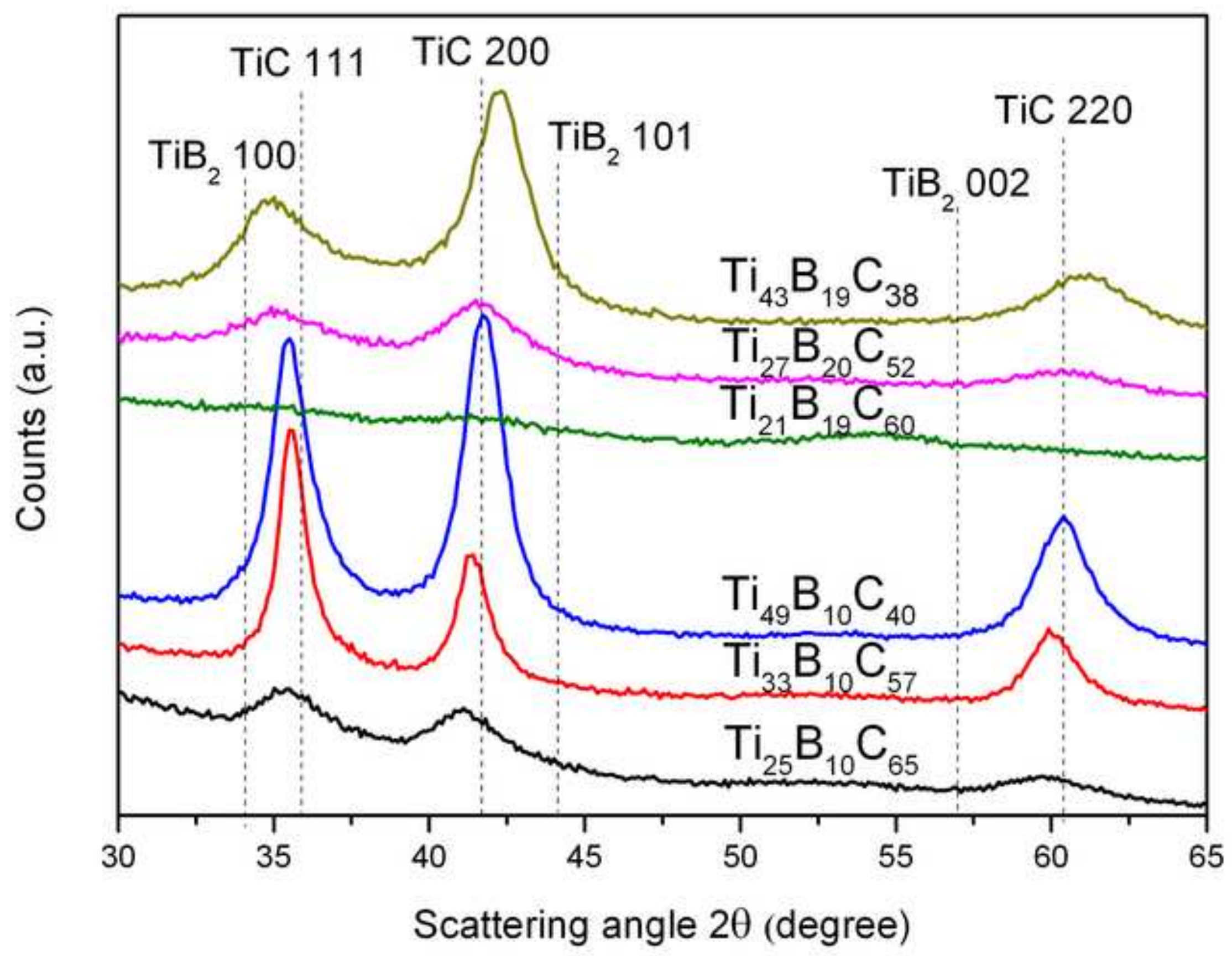


a)

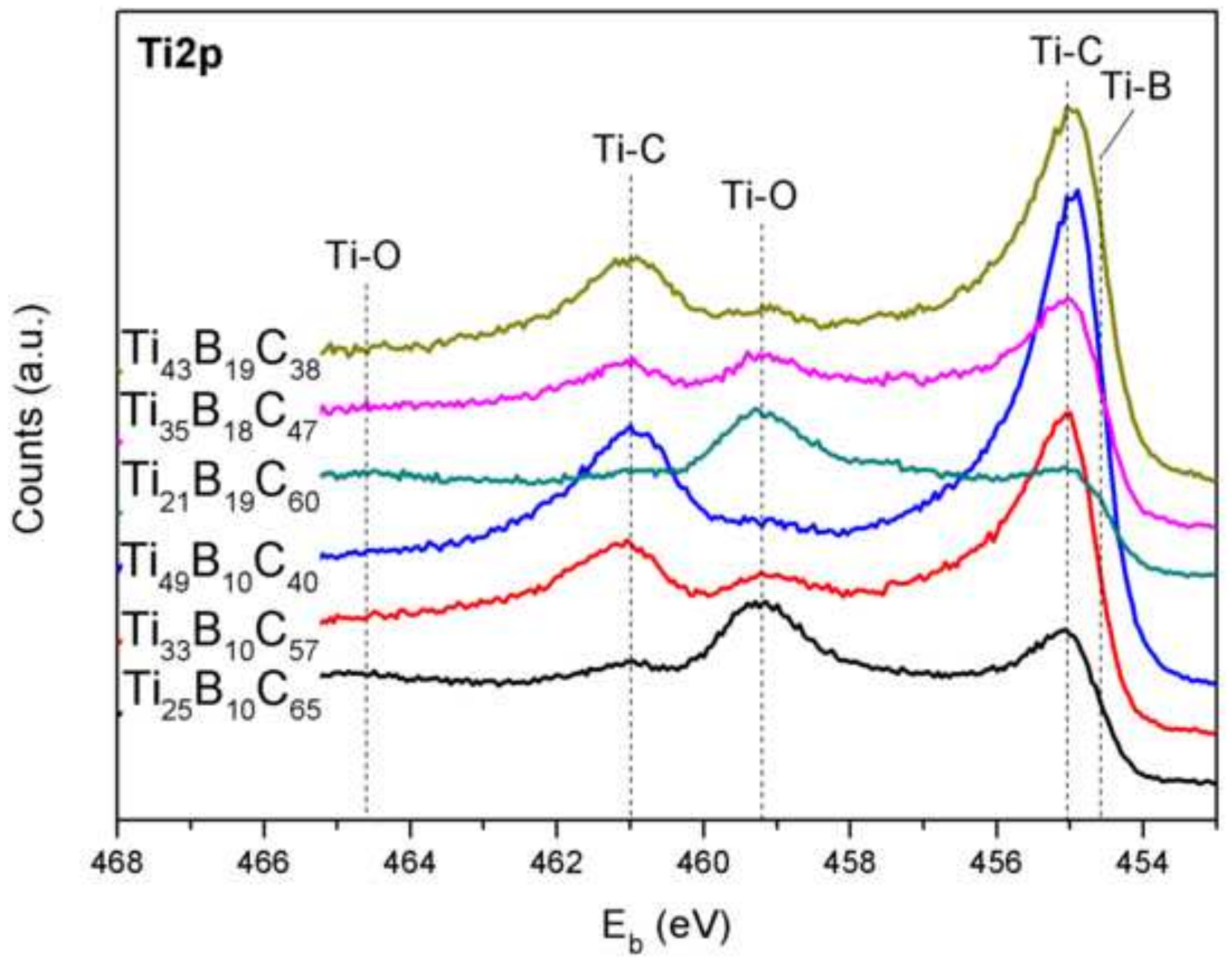


b)

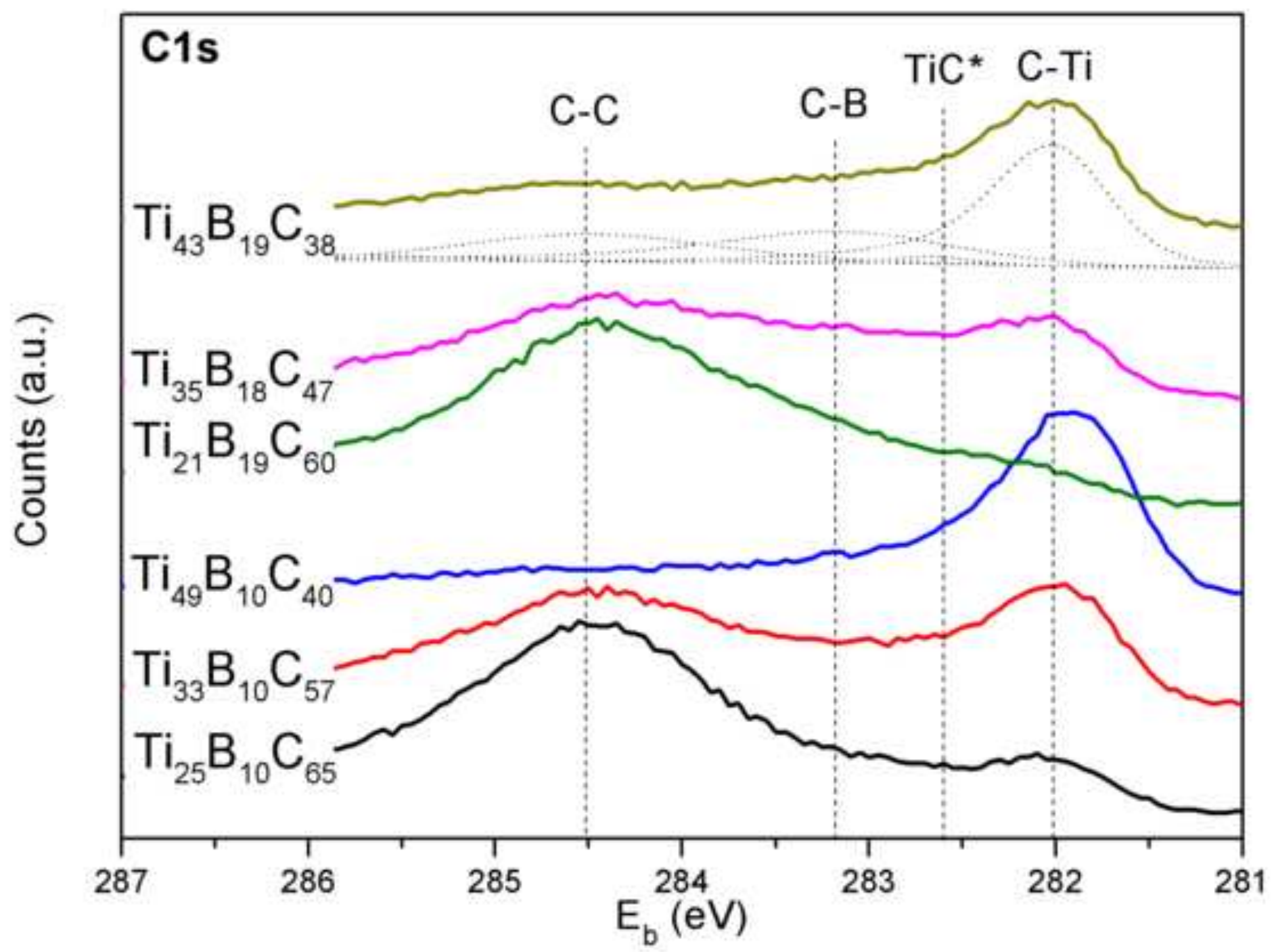


c)

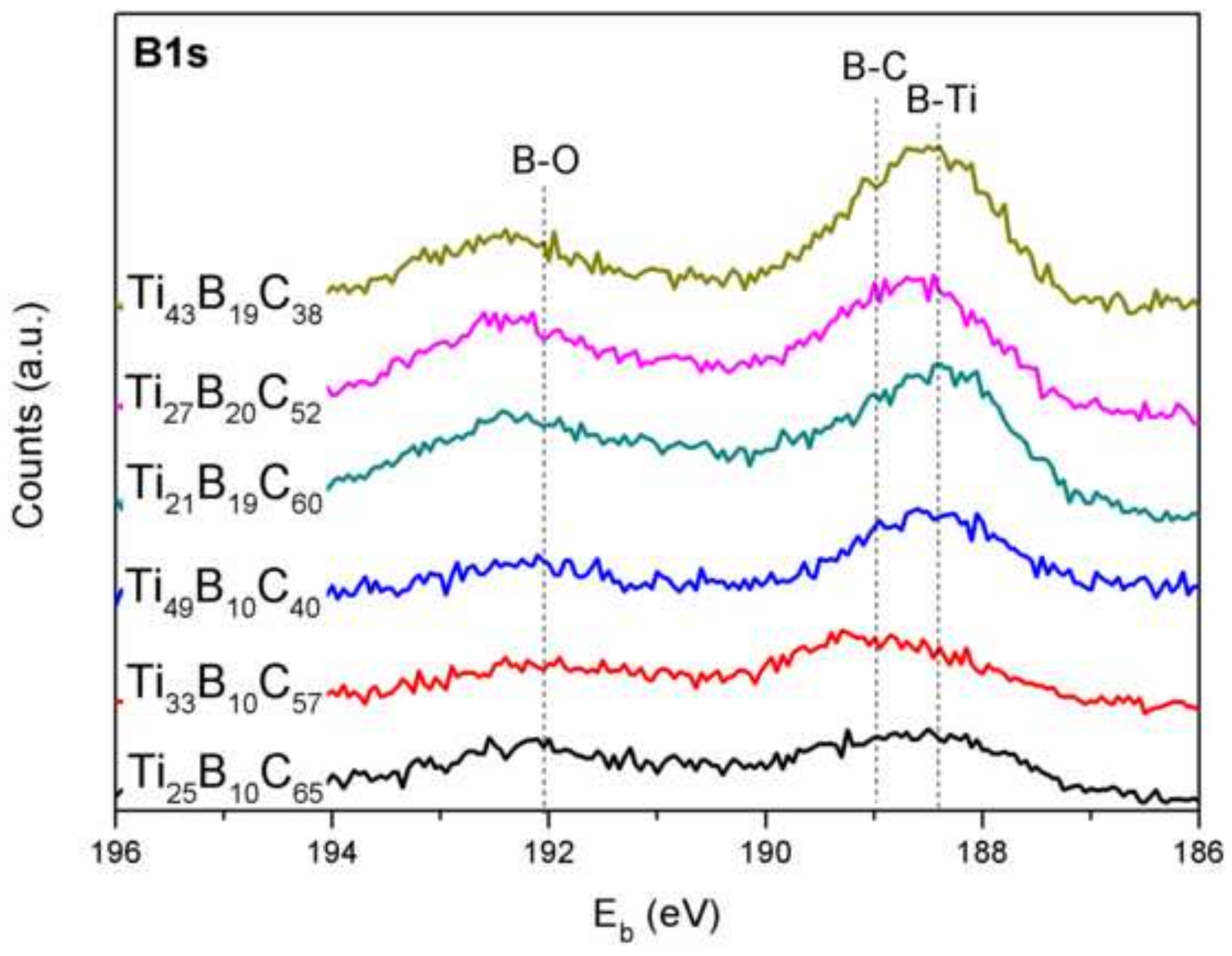




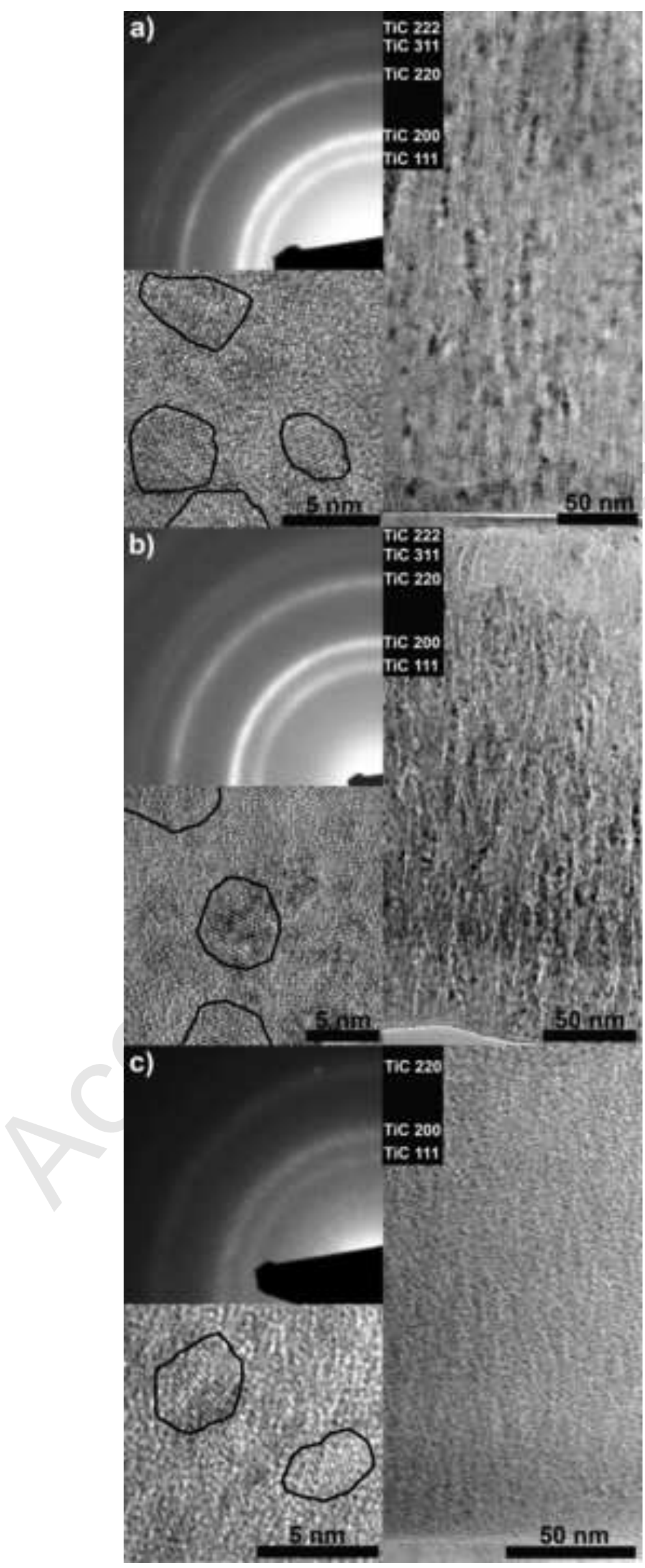




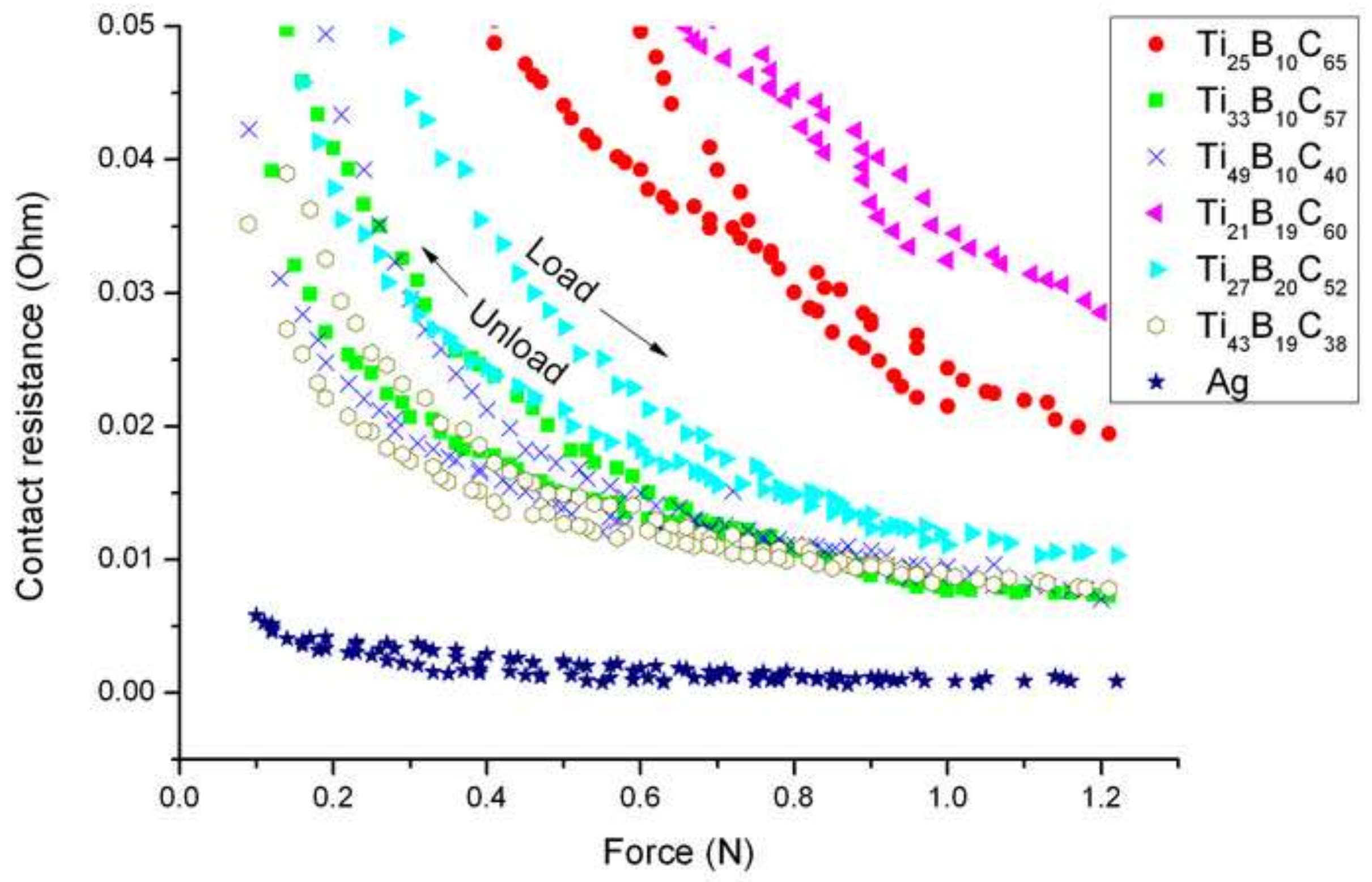

